\title{
Management of the Falkland Islands Multispecies Ray Fishery: Is Species-specific Management Required?
}

\author{
R. C. Wakeford ${ }^{1}$ and D. J. Agnew \\ Renewable Resources Assessment Group, Imperial College \\ Prince Consort Road, London SW7 2BP, United Kingdom \\ and
}

\author{
D. A. J. Middleton, J. H. W. Pompert and V. V. Laptikhovsky \\ Fisheries Department, Falkland Islands Government \\ P. O. Box 598, Stanley, Falkland Islands
}

\begin{abstract}
Wakeford, R. C., D. J. Agnew, D. A. J. Middleton, J. H. W. Pompert, and V. V. Laptikhovsky. Management of the Falkland Islands Multispecies Ray Fishery: Is Species-specific Management Required? J. Northw. Atl. Fish. Sci., 35: 309-324. doi:10.2960/J.v35.m497
\end{abstract}

\begin{abstract}
A multispecies commercial fishery for rajids has been managed in Falkland Islands waters since 1987. In the absence of detailed biological knowledge and catch-at-age data, management policies currently consider a single assemblage rather than individual species. Simple production models with aggregated catch and effort data are used to estimate sustainable levels of exploitation. Biological data, now available from recent research surveys and an ongoing observer program, provide an opportunity to examine the potential impact of the rajid fishery at a species level. This in turn will help determine whether current management policies are still appropriate.
\end{abstract}

\begin{abstract}
An updated assessment of the northern ray population indicates that the assemblage has been surprisingly robust to fluctuations in fishing pressure. A spatial analysis of the relative abundance of animals showed no evidence of local depletions in biomass. At a species level, a declining trend in the relative abundance of three species (Bathyraja griseocauda, B. multispinus, and an undescribed Bathyraja sp. 3) was found at the same time as an increase in two Rajid species ( $R$. doellojuradoi and $R$. flavirostris). A preliminary analysis of the distribution and movements of $R$. flavirostris, coupled with length frequency and maturity data, suggest that this species has a broad distribution, which, unlike $B$. griseocauda, may not form a resident population within Falkland Island waters. While no loss of diversity has been reported, closure of the once heavily exploited area to the south of the Islands provides at least one refuge for species such as B. griseocauda.
\end{abstract}

Key words: ray, fishery, Falkland Islands, catch trends, stock assessment, distribution, sustainable management

\section{Introduction}

Rajid catches around the Falkland Islands have been recorded since the establishment of the Falkland Islands Interim Conservation and Management Zone (FICZ) in 1987 (Fig. 1). Catches during the 1980s were taken primarily as part of a general mixed groundfish fishery by Spanish vessels and were less than 1500 tonnes annually. However, in 1989 a Korean fleet entered the fishery, specifically targeting rajids and by 1991 annual catches had risen to more than 7000 tonnes (see Table 1). Catches peaked in 1993 at 8523 tonnes (Falkland Islands Government, 2002).

In December 1990, the Falklands Outer Conservation Zone (FOCZ) was established extending to $200 \mathrm{~nm}$ from coastal baselines (Falkland Islands Government, 1997).
Most of this area is too deep for conventional trawling, but there is a small amount of licensed longlining targeting patagonian toothfish (Dissostichus eleginoides) and a small by-catch of rajids results.

Prior to 1993, there had been no specific management for rays. In the face of this rapidly developing directed skate and ray fishery, management controls, in the form of specific licences, were first introduced in August 1994. The rajid catch declined following this move primarily in response to the reduction in directed effort. However, it became apparent that there were two distinct rajid fishery areas in the Falklands: a small area to the south of the Islands and a more extensive northern area, in particular the slope areas of 200-300 m depths. These both contained multispecies complexes, but were apparently distinct from each other with differing stock dynamics and detailed 


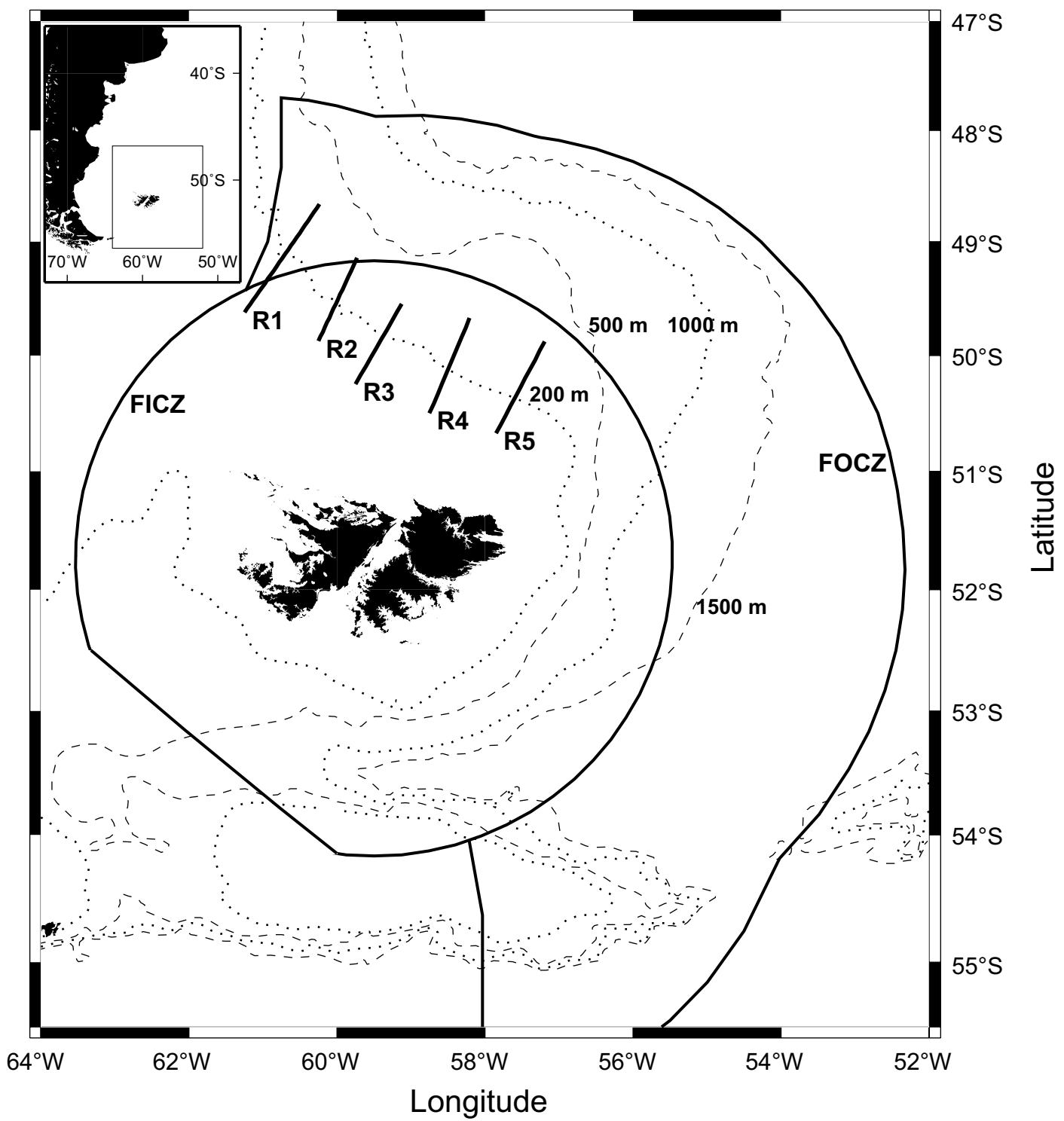

Fig. 1. The Falkland Islands and the Falkland Islands Interim Conservation and Management Zone (FICZ) and Falklands Outer Conservation Zone (FOCZ). Lines R1-R5 indicate transects used for research cruise carried out from 26 July to 3 August 2000.

species make-up (Agnew et al., 2000). Stock assessments undertaken in 1995 detected a continuing decline in the catch-per-unit-effort (CPUE) from the stock situated to the south of the Islands, due in particular to declining abundance of Bathyraja griseocauda. To protect this area, directed fishing for rays was prohibited south of $52^{\circ} \mathrm{S}$ latitude from 1996 onwards (Agnew et al., 1999). The directed rajid trawl fishery is therefore currently restricted to waters north of the Islands.

There are two seasons to the Falkland Islands fishing year, the first running from January to June and the second from July to December. Most of the rajid trawl fishery has taken place in the second season when the primarily Korean fleet targets rays and finfish to the north of the Islands. The mixed nature of the northern rajid assemblage prevents single species targeting and consequently catches in this fishery are always of mixed species. More than twenty different rajid species have been recorded from catches around the Islands and the dominant species in the commercial fishery are listed in Table 2.

The Falkland Islands Government has the longterm maintenance of sustainable fisheries as its primary 
TABLE 1. Total annual catches of rays (directed and by-catch) for all vessels operating in Falkland Islands' waters, total annual catches and tuning catch and effort during 1991-2001 for licensed vessels operating north of $52^{\circ} \mathrm{S}$ latitude, and Argentine total rajid catches during 1987-98.

\begin{tabular}{lcrrrr}
\hline \hline & & \multicolumn{3}{c}{ Northern ray population } & \\
\cline { 3 - 4 } Year & $\begin{array}{c}\text { Falkland Island } \\
\text { Total Catch (tonnes) }\end{array}$ & $\begin{array}{l}\text { Catch } \\
\text { (tonnes) }\end{array}$ & $\begin{array}{c}\text { Tuning catch } \\
\text { (tonnes) }\end{array}$ & $\begin{array}{r}\text { Tuning effort } \\
\text { (hrs) }\end{array}$ & $\begin{array}{c}\text { Argentine EEZ } \\
\text { Total catch (tonnes) }\end{array}$ \\
\hline 1987 & 458 & 257 & - & - & 200 \\
1988 & 1579 & 819 & - & - & 500 \\
1989 & 1762 & 996 & - & - & 1000 \\
1990 & 1500 & 1074 & - & - & 500 \\
1991 & 6938 & 6067 & 5583 & 14655 & 200 \\
1992 & 8032 & 3798 & 2565 & 11186 & 800 \\
1993 & 8523 & 6364 & 5676 & 21990 & 1000 \\
1994 & 5501 & 4676 & 4098 & 11930 & 6000 \\
1995 & 5258 & 4611 & 4003 & 15159 & 7000 \\
1996 & 3167 & 2992 & 2411 & 9678 & 12000 \\
1997 & 3196 & 2995 & 2362 & 7913 & 10500 \\
1998 & 997 & 851 & 232 & 612 & 14000 \\
1999 & 3736 & 4511 & 3890 & 10413 & na \\
2000 & 3649 & 3437 & 2643 & 7891 & na \\
2001 & 4200 & 4012 & 3280 & 8493 & na \\
\hline
\end{tabular}

${ }^{1}$ Data source: García de la Rosa et al., 2000.

2 n.a. - not available.

TABLE 2. Major ray species caught in the northern multi-species fishery around the Falkland Islands. Catch percentages are for regions north of $52^{\circ} \mathrm{S}$ latitude between 1993 and 2002. Size information is based on all samples between 1993 and 2001.

\begin{tabular}{|c|c|c|c|c|c|c|}
\hline \multirow[b]{2}{*}{ Species } & \multirow{2}{*}{$\begin{array}{l}\text { Percentage } \\
\text { in catch }\end{array}$} & \multicolumn{3}{|c|}{ Disc width $(\mathrm{cm})$} & \multicolumn{2}{|c|}{ Weight (g) } \\
\hline & & Min. & Mean & Max. & Min. & Max. \\
\hline Bathyraja griseocauda & 24.2 & 8 & 4.25 & 130 & 30 & 30400 \\
\hline Bathyraja albomaculata & 22.0 & 7 & 35.4 & 55 & 20 & 3900 \\
\hline Bathyraja brachyurops & 20.4 & 8 & 38.2 & 83 & 6 & 14000 \\
\hline Raja flavirostris & 13.3 & 12 & 57.9 & 115 & 60 & 25000 \\
\hline Bathyraja sp. 3 & 7.2 & 7 & 38.7 & 92 & 14 & 18600 \\
\hline Bathyraja macloviana & 3.9 & 8 & 30.0 & 55 & 14 & 3200 \\
\hline Bathyraja scaphiops & 3.5 & 10 & 24.5 & 74 & 25 & 8500 \\
\hline Raja doellojuradoi & 2.4 & 7 & 28.2 & 47 & 10 & 2200 \\
\hline Bathyraja multispinis & 2.4 & 9 & 47.6 & 98 & 20 & 20000 \\
\hline Psammobatis spp. & 0.4 & 7 & 23.2 & 43 & 15 & 1480 \\
\hline Bathyraja magellanica & 0.3 & 9 & 29.5 & 55 & 40 & 3600 \\
\hline
\end{tabular}

fisheries policy aim. This, of course, includes the rajid fishery. Stock assessment and licensing levels to date have necessarily treated the multispecies complex as a single unit. However, data from fisheries observers and research cruises are being gathered with the long-term aim of understanding the biology, ecology and effect of fishing on individual species. In this paper, we examine the current status of the stock as a single multispecies assemblage.
We investigate whether this approach is potentially masking local declines in abundance, and describe aspects of the distribution and dynamics of particular rajid species that will influence the impact of the fishery on individual species. This highlights the question of whether management approaches must address the conservation of individual species, and overall biodiversity, in addition to long-term sustainability of the multispecies fishery. We 
restrict our attention to data from the northern ray fishery that is the target of the licensed ray fleet.

\section{Materials and Methods}

\section{Fishery data}

Two sources of data are available from the commercial fishery. Each licensed vessel reports total daily catch and fishing time together with position at midday and midnight on a $0.25^{\circ}$ latitude by $0.5^{\circ}$ longitude grid. Fisheries observers are placed on a subset of licensed vessels to record species catch composition and biological information. In the licensed ray fleet, the need to keep sampled animals intact limits the extent to which ray maturity can be assessed. Only males are classified, using a simplified three-stage maturity scale (Table 3).

\section{Stock assessment}

Assessments of the northern ray stock are currently restricted to simple biomass dynamic models. This paper updates a previous assessment based on an equivalent geographic area by Agnew et al. (2000) using the Schaefer production model with a 2-year time lag in biomass (see Table 6 in Agnew et al., 2000). Total ray catches and a tuning series derived from a subset of catch and effort data from the licensed ray fleet have been extended to the end of 2001 (see Table 1). The assessment was performed using the catch and effort data analysis (CEDA) software (Holden et al., 1995) and a series of ad hoc spreadsheets. To facilitate direct comparison between the previous and latest assessment, fitted parameters from both analyses were used to construct two time-series of annual biomass.

Raja flavirostris (also reported as Dipturus chilensis) is subject to heavy fishing pressure within the Argentine EEZ (Cousseau and Perrotta, 2000). Although Argentine catch statistics indicate rajids have been exploited since 1985, it was not until 1994 that total annual catches exceeded 6000 tonnes (García de la Rosa et al., 2000). Increased catches within Argentine waters could be linked to the observed decline in catch rates reported within the FICZ during mid-1990s. To investigate this hypothesis, an additional assessment was undertaken which combined both Falkland Islands and Argentine catch statistics (see Table 1).

\section{Trends in CPUE}

The current assessment model has no spatial component within the northern ray fishery. A potential concern is that the fleet is sequentially targeting different areas to maintain high catch rates, which may mask severe local depletions and a decline in the overall stock.

The distribution of daily CPUE of ray licensed vessels was investigated on an annual basis. The midday positions of fishing by ray licensed vessels were distributed over 124 grid cells. To remove grid cells fished only occasionally, or which were incidental positions of a steaming vessel, only grid cells with more than ten daily catch reports over the course of the licensed fishery were considered. A linear regression of daily CPUE on year was fitted for each of the remaining 56 grid cells.

Local depletions however, could be masked by changes in relative species abundances. This potential masking effect was explored further by looking at individual species CPUE trends. Fisheries observers identify the catch by species on a trawl by trawl basis and this allows the investigation of individual species CPUE. To maintain temporal consistency, and so minimise the potential effects of migrations, observer data from August and September only were used. Trawls were observed over a wide range of fishing depths (50-1850 m) and, therefore, analysis has been restricted to trawls in the depth range 200-300 m (Fig. 2). Limited data available between 1996 and 1998 meant that trawls have been grouped into three periods: 1992-94, 1995-97 and 1999-2001.

\section{Distribution and movement of rajid species}

Attempts to infer the distribution patterns of rajid species from observer data are confounded by limited temporal and spatial coverage. To provide a consistent estimate of the variation in distribution over a wide area and depth range, a research cruise was undertaken from 26 July to 3 August 2000. Five cross-slope transects

TABLE 3. Maturity scale for male rajids based on clasper characteristics only, as used by observers on ray licensed vessels in the Falkland Islands fishery.

\begin{tabular}{cll}
\hline $\begin{array}{c}\text { Maturity } \\
\text { stage }\end{array}$ & \multicolumn{1}{c}{ Description } & \multicolumn{1}{c}{ Characteristics } \\
\hline I & Immature & Claspers do not extend beyond the tip of the pelvic fin \\
II & Maturing/Adolescent & Claspers soft and flexible, extend beyond the pelvic fins \\
III & Mature & Claspers are rigid and are at maximum length \\
\hline
\end{tabular}




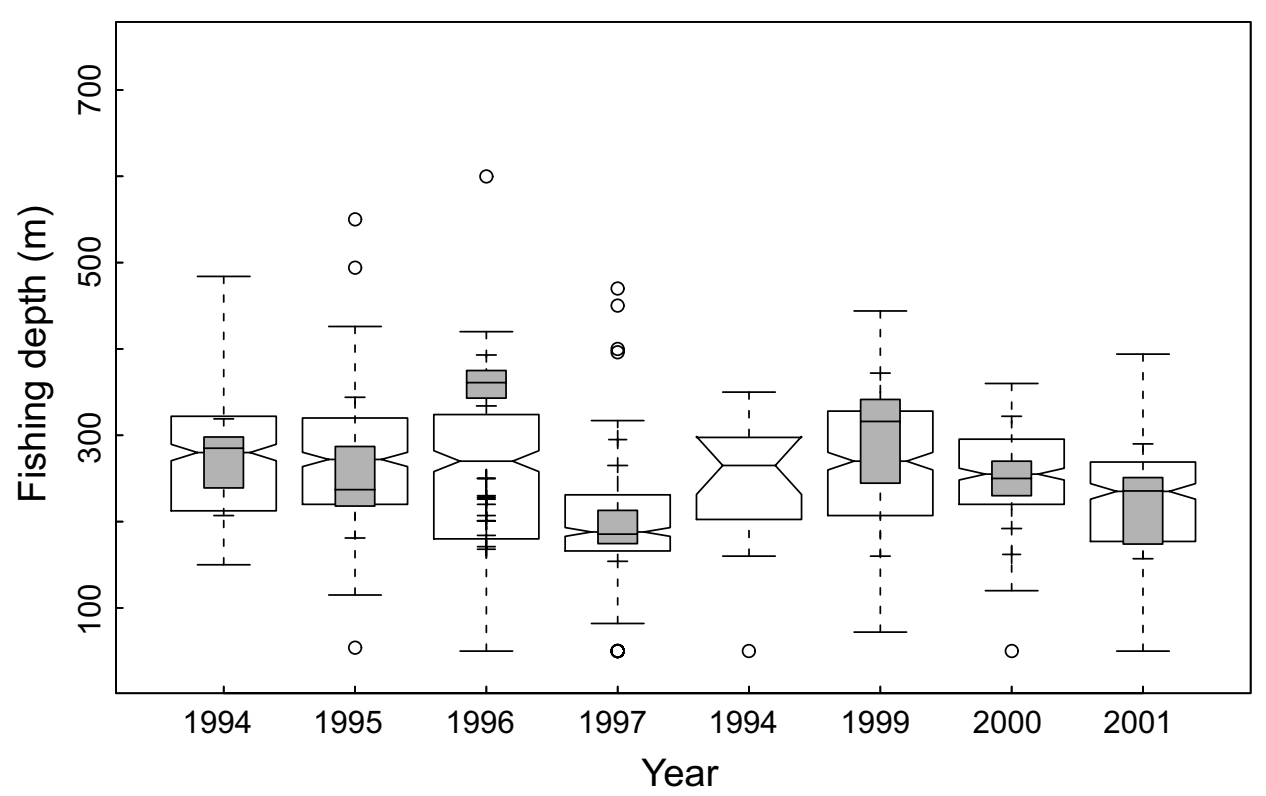

Fig. 2. The annual distribution of mean daily fishing depth of the ray licensed fleet (unfilled box plots, circular outliers) in August and September, together with the depth distribution of observed trawls (grey box plots, crosses marking outliers).

(designated R1-R5) were placed to cover the main area fished by the licensed ray fleet (see Fig. 1). Trawls were carried out at depths of 120-150 m ("150 m"), 200-250 m ("200 m") and 350-400 m ("350 m") on each transect. Weather conditions prevented fishing of the deepest station on Transect R3 and of all three stations on Transect R4. All rays caught were identified to species and catches recorded both in catch weight and number of individuals.

Although biological data is necessarily restricted in both temporal and spatial coverage, two periods were observed during 2000 and 2001. Data from these observed trips (in September and October-November 2000 and August and November 2001) have been used to investigate the movement of two species: Raja flavirostris and Bathyraja griseocauda. The monthly distributions of trawl by trawl CPUE were investigated in two regions, east and west of $60^{\circ} \mathrm{W}$, and two depth ranges (100-199 m and 200-299 m). Sex ratios were also calculated by depth range.

\section{Diversity indices}

A preliminary exploration of the diversity of the northern ray assemblage was expressed using the Shannon diversity index $(H)$ and a measure of equitability $\left(E_{H}\right)$ (see Zar, 1999). These measures attempt to account for both the abundance and evenness of the species present and assume that they are all equally vulnerable to the sampling gear, in this case a trawl.

Indices were calculated for observed trawls using catch weight data collected from five ray licensed vessels operating at depths ranging 150-350 m during the twomonth period August-September each year from 1994 to 2001. Trawl data were also spatially resolved into two regions, east and west of $60^{\circ}$ latitude. In addition, diversity indices were calculated based on data from eleven research trawls (see distribution and movement of rajid species section above).

\section{Results}

\section{Stock assessment}

The latest assessment shows higher estimates of initial biomass $\left(B_{0}\right)$ and $M S Y$ than that reported by Agnew et al. (2000) (Table 4). Confidence limits for all parameters however, remain wide, and, for $B_{0}$, are highly skewed. The intrinsic rate of population growth $(r)$ also remains particularly high.

Raising the annual biomass of the previous assessment by a proportion of the latest estimate of initial biomass (49 622 tonnes) reveals a number of consistent trends (Fig. 3). High catches during the early-1990s coincide with a depletion of the initial stock biomass by approximately 
TABLE 4. Parameter estimates from Schaefer production model using CEDA software from Agnew et al. (2000) and current assessment (95\% confidence limits available for 2002).

\begin{tabular}{lrrr}
\hline \hline Parameter & 1999 & 2002 & $95 \% \mathrm{CI}_{2002}$ \\
\hline$B_{0}$ & 36224 & 49622 & $30034-119416$ \\
$r$ & 0.619 & 0.590 & $0.348-0.990$ \\
$q$ value & $1.06 \mathrm{E}^{-05}$ & $7.70 \mathrm{E}^{-06}$ & $2.81 \mathrm{E}^{-06}-1.61 \mathrm{E}^{-05}$ \\
$M S Y$ & 5606 & 7319 & $4938-18947$ \\
\hline
\end{tabular}

$30 \%$. Following a decline in fishing effort in the latter half of the decade, stock biomass has been shown to recover over the same period. The addition of Argentine catch data did not improve the model fit, and resulted in even wider confidence limits for each parameter (not shown).

\section{Trends in CPUE}

Mapping the annual distribution of fishing effort by the ray licensed vessels demonstrates the areas fished and shows some inter-annual variation. This is illustrated for
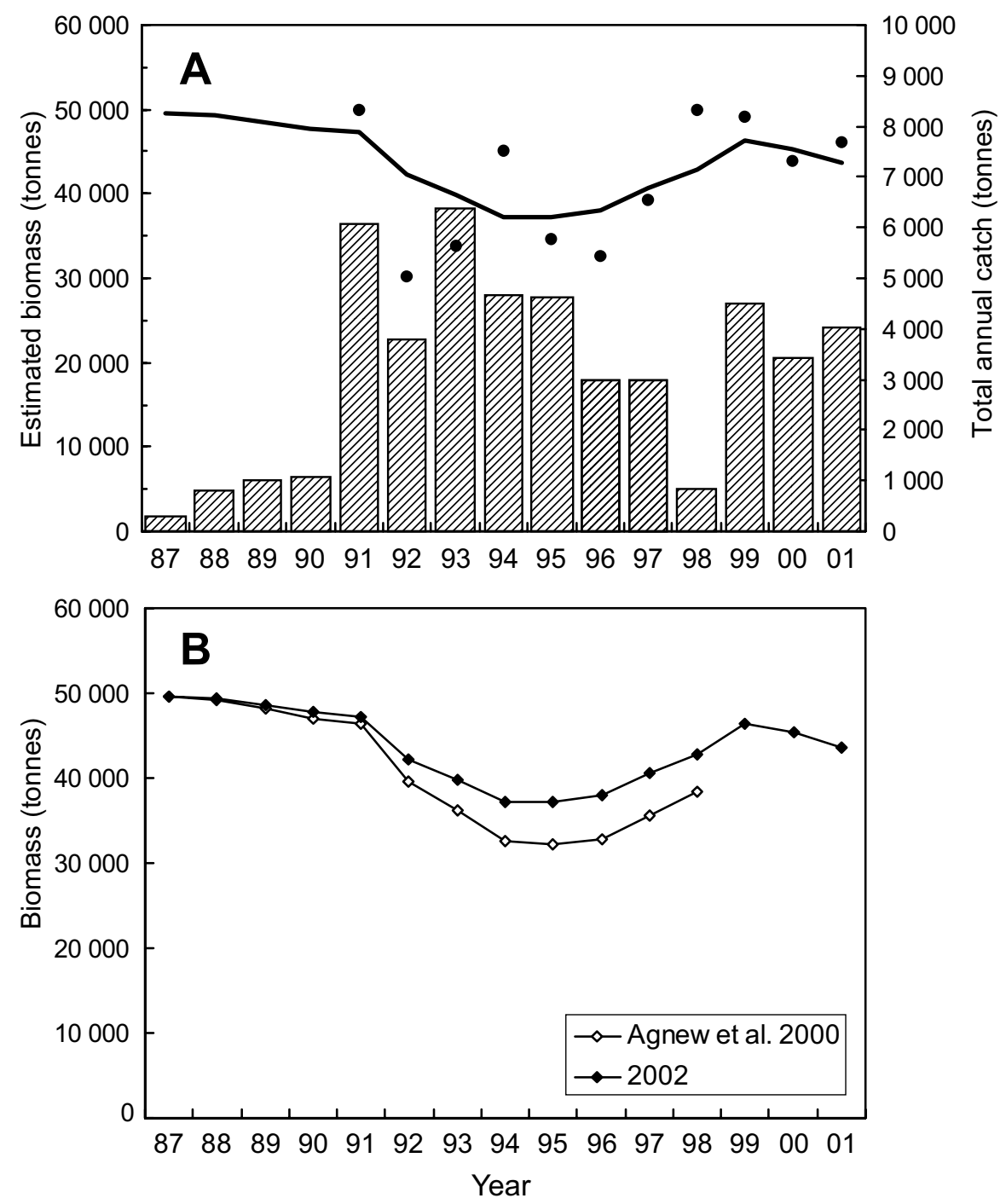

Fig. 3. (A) Total catches (vertical bars) and estimated biomass (line) of the northern skate and ray stock and associated tuning series (solid dots). (B) Comparative annual biomass calculated from total catches and parameters of Schaefer production model by Agnew et al. (2000) and current assessment. 
two years, 1996 and 2001, in Fig. 4. In both these years the slope north of the Falkland Islands was the subject of high fishing effort. However, in 1996 the deeper shelf to the north-east was fished heavily, whereas in 2001 effort increased on the shallower shelf areas in the northwest and immediately north of the Islands. Of the 64 grid cells with fishing effort in 2001, only 39 were also fished in 1996. Changes in the distribution of fishing effort might suggest that fishers target regions of high ray abundance, thus creating local depletions. However, there were no consistent trends in the distribution of daily CPUE for each grid cell. Eighteen out of 56 grid cells showed a significant linear trend when daily CPUE was regressed against year, but only in two cases was this trend negative.

To examine whether the stability of catch trends observed within each grid cell had been masked by changes in the relative species abundances, the distribution of CPUE for each species was examined for three time periods (Fig. 5). For some species (i.e. Bathyraja albomaculata, B. brachyurops, B. macloviana, and B. scaphiops), there was little indication of a trend in CPUE. In the two Raja species (Raja doellojuradoi and R. flavirostris), CPUE appears to have steadily increased over the three periods, whereas in three species (Bathyraja griseocauda, B. multispinis and the undescribed Bathyraja sp. 3) there were indications of a decline in CPUE. The apparent decline was especially marked in the case of $B$. griseocauda, whereas the undescribed Bathyraja sp. 3 has apparently undergone a sharper decline with only very low CPUEs in the middle and late periods.

\section{Distribution and movement of rajid species}

The proportion of different ray species caught at eleven research trawl stations is illustrated in Fig. 6. Bathyraja albomaculata was present at all stations. Bathyraja brachyurops was caught only at the 150 and $200 \mathrm{~m}$ stations, with a noticeable increase in its proportion in the catch on the easterly Transect R5. With the exception of the $350 \mathrm{~m}$ station on Transect R1, Raja flavirostris was also only caught at the 150 and $200 \mathrm{~m}$ stations, but was entirely absent from the most eastern transect.

The smaller $R$. doellojuradoi was present at all 200 and $350 \mathrm{~m}$ stations but was caught only, at low abundance, at two of the $150 \mathrm{~m}$ stations. Bathyraja griseocauda was a significant component of the catch at the 200 and $350 \mathrm{~m}$ stations, but formed just a small part of the catch at two of the $150 \mathrm{~m}$ stations. The occurrence and proportion of the undescribed Bathyraja sp. 3 in catches increased with depth. Bathyraya multispinis and B. scaphiops also increased in occurrence and proportion of the catch in the
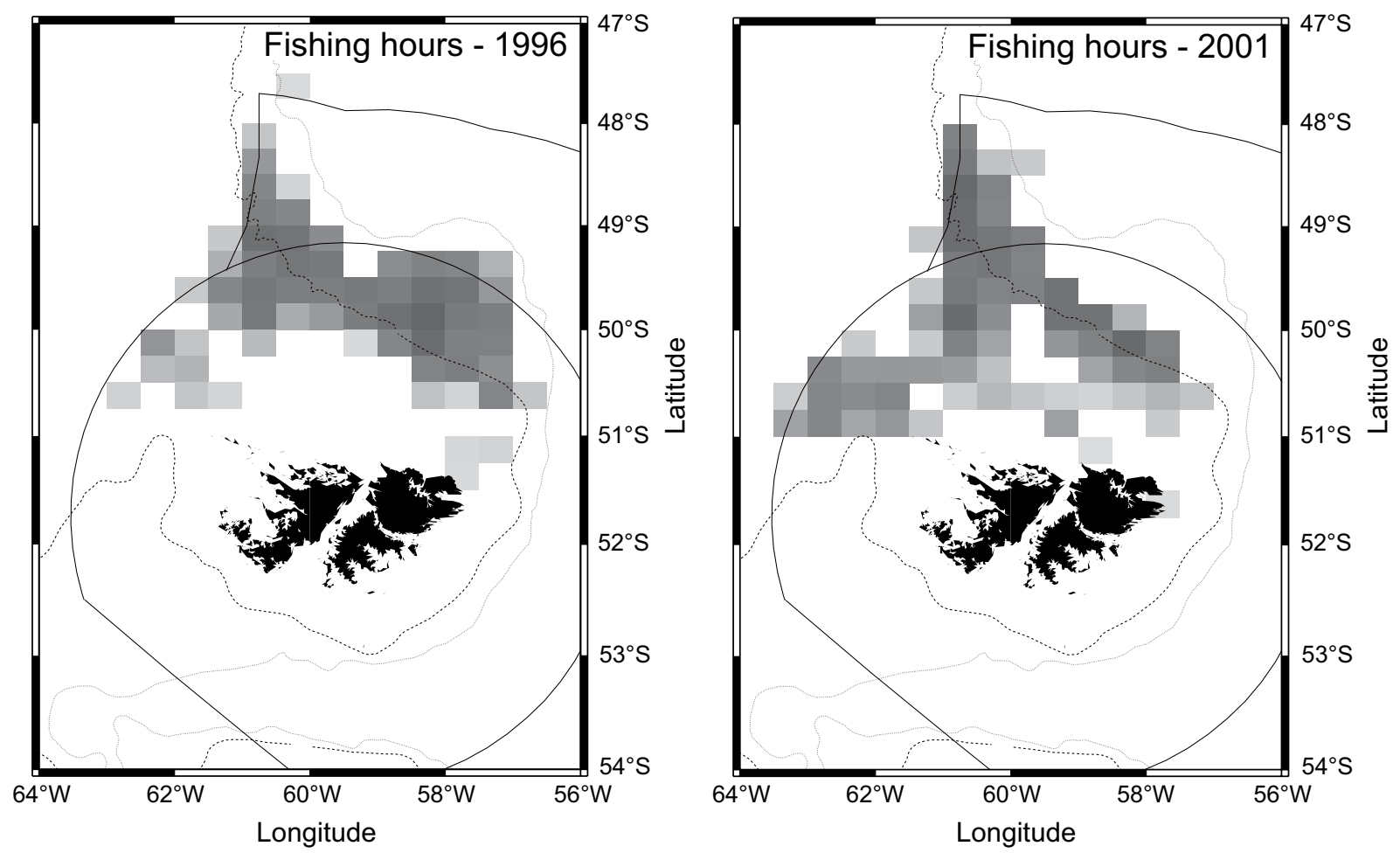

Fig. 4. The distribution of fishing effort by the licensed ray fleet in 1996 and 2001. 

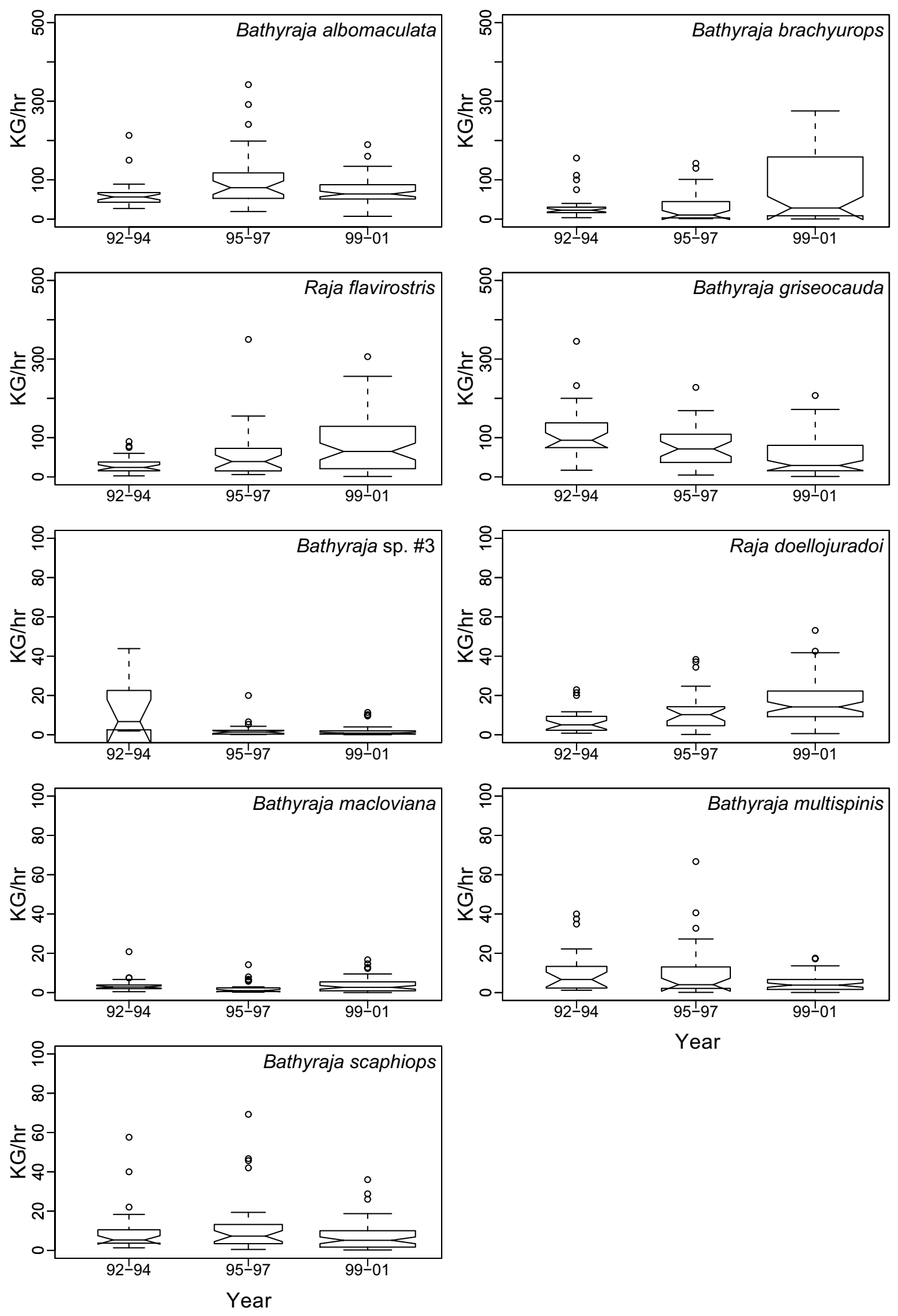

Fig. 5. Distribution of individual species CPUE from observer data using only trawls in the depth range 200-300 m. 
A
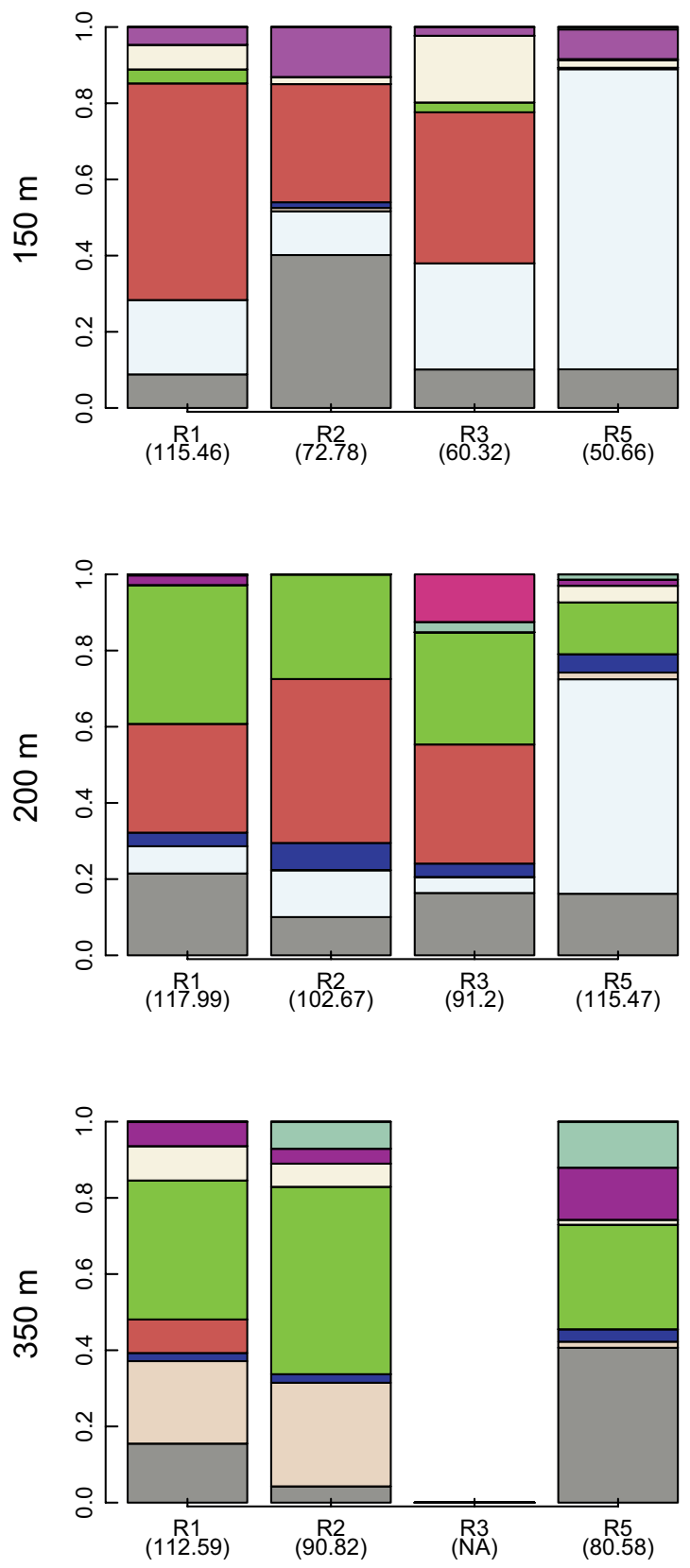

B
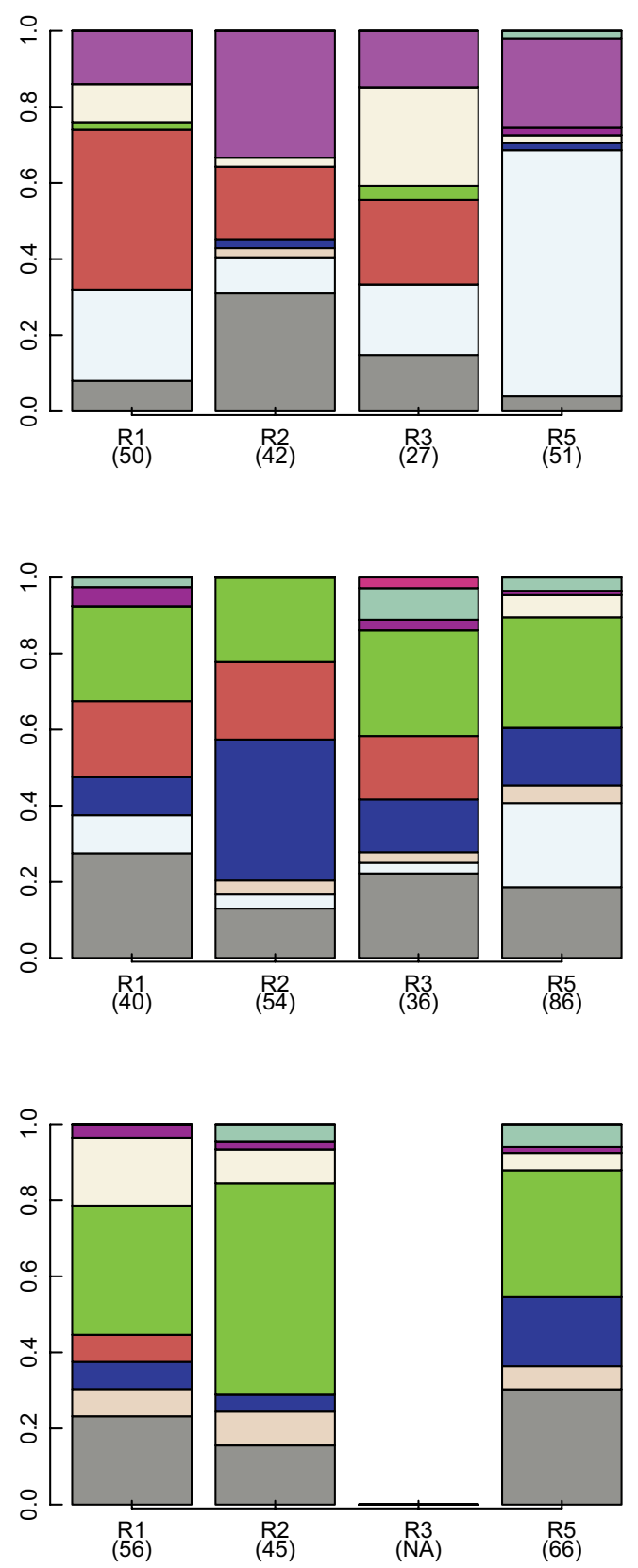

\begin{tabular}{lllll}
$\square$ Bathyraja albomaculata & $\square$ Raja flavirostris & $\square$ Psammobatis spp. \\
$\square$ Bathyraja brachyurops & $\square$ Bathyraja griseocauda & $\square$ Bathyraja scaphiops \\
$\square$ Unidentified ray \#3 & $\square$ Bathyraja macloviana & $\square$ Raja trachyderma \\
$\square$ Raja doellojuradoi & $\square$ Bathyraja multispinis & & \\
\hline
\end{tabular}

Fig. 6. Proportion of different ray species in research trawls (26 June to 3 August 2000) in terms of (A) catch weight and (B) numbers caught. Total weight and number of animals at each station is given in parenthesis. 
deeper stations. Psammobatis spp. were restricted to the $150 \mathrm{~m}$ stations. On the three more westerly transects, $B$. macloviana occurred only at the 150 and $250 \mathrm{~m}$ stations, but was present at the $200 \mathrm{~m}$ station on the most eastern transect.

Raja flavirostris had its highest catch rates in shallower trawls west of $60^{\circ}$ latitude during 2000 (Fig. 7). Within this area, catch rates declined from September through to November. A similar decline is observed in deeper trawls, although regional differences are less marked. In 2001, a similar pattern is observed in shallow water, although in the 200-299 m depth range, catch rates were considerably higher in the eastern region than elsewhere during August. By November, however, catch rates had declined in the eastern region, but increased in the west. Catch rates for B. griseocauda were, as expected, considerably higher in the deep trawls than in the shallower trawls, but there were no major differences observed in regional or temporal catch rates (Fig. 8).

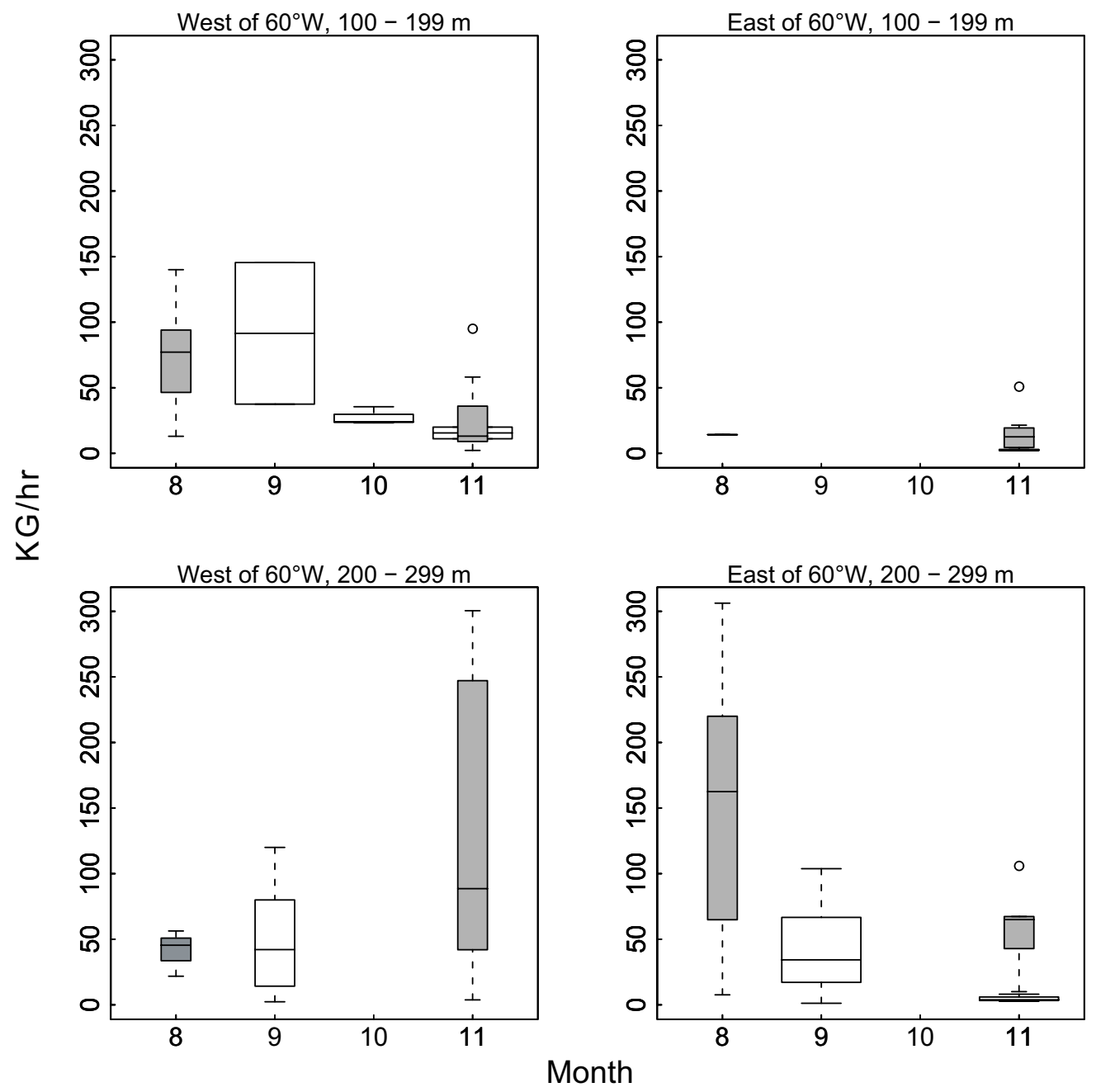

Fig. 7. Monthly distributions of trawl by trawl CPUE $(\mathrm{kg} / \mathrm{hr})$ for Raja flavirostris. Trawls have been divided into two regions, east and west of $60^{\circ} \mathrm{W}$, and two depth ranges (100-199 $\mathrm{m}$ and 200-299 m). The wider, unshaded boxplots are data from 2000, whereas the narrower, grey boxplots are data from 2001. 

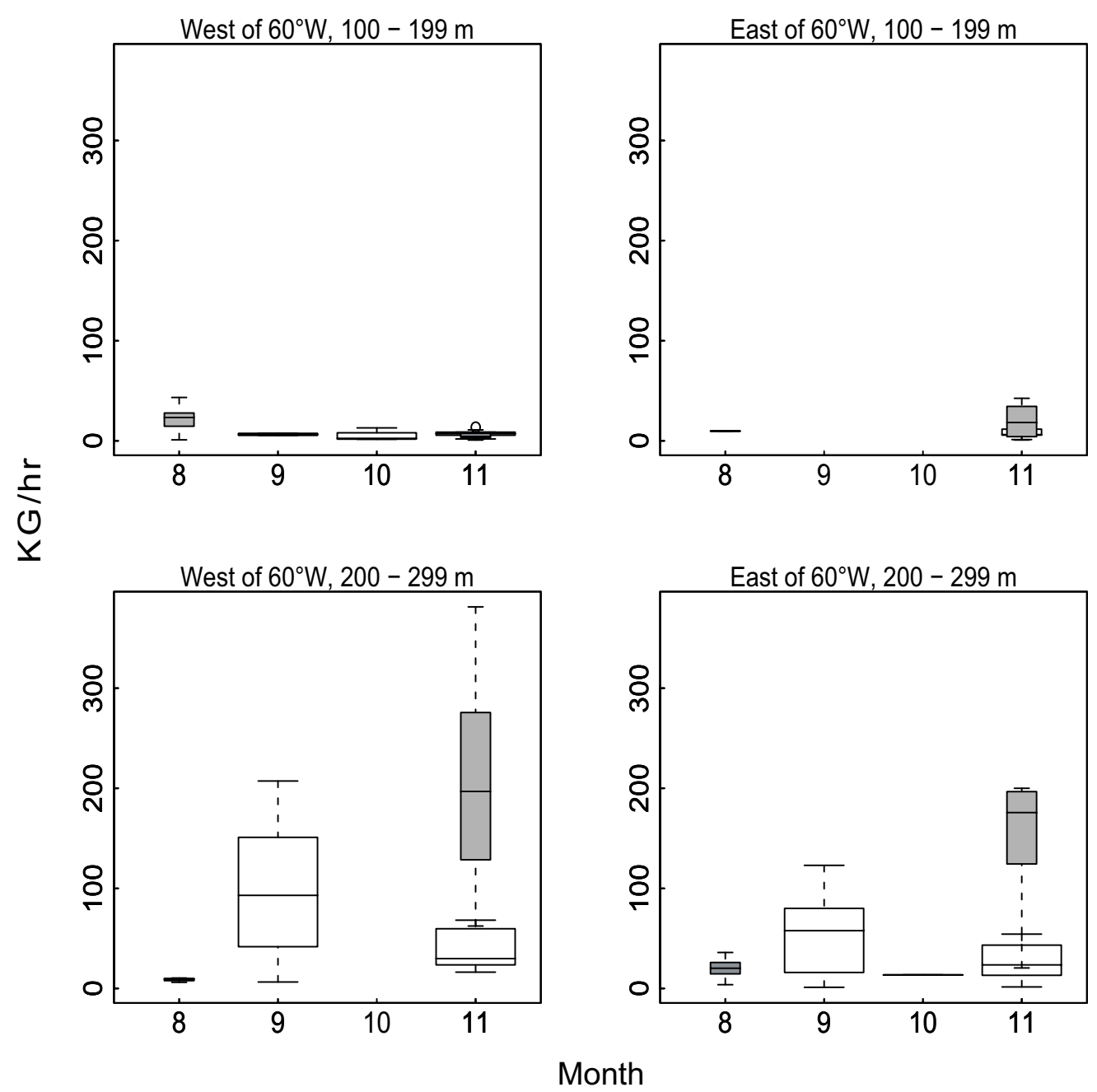

Fig. 8. Monthly distributions of trawl by trawl CPUE $(\mathrm{kg} / \mathrm{hr})$ for Bathyraja griseocauda. Other features as Fig. 7.

A clear predominance of female $R$. flavirostris was observed in the catches that slightly increase over the period from August to November. In contrast, the proportion of female B. griseocauda was much closer to equality (Fig. 9).

Length frequency data (Fig. 10) illustrate that few small (and immature) Raja flavirostris were found in Falkland Islands waters, whereas all sizes of $B$. griseocauda were present. The smallest $B$. griseocauda were found in deeper water, beyond the normal fishing depths of the ray fleet, but present as occasional by-catch for other fleets.

\section{Maturity and size distribution}

Although both Raja flavirostris and Bathyraja griseocauda have relatively large adults, they show opposite trends in CPUE over the period of the fishery. In $R$. flavirostris $50 \%$ of males were mature at a disk width of approximately $64 \mathrm{~cm}$, whereas in B. griseocauda $50 \%$ maturity was reached at a disk with of $77 \mathrm{~cm}$. When compared with their size frequency distribution, $12.8 \%$ of sampled R. flavirostris males had disk widths of $64 \mathrm{~cm}$ and above, whereas in B. griseocauda only $4.6 \%$ of males were above the size at $50 \%$ maturity (Fig. 11).

\section{Diversity}

A summary of the diversity indices calculated for the research trawls is presented in terms of catch weight (Table 5) and catch numbers (Table 6). In terms of catch weight, the mean diversity index and mean equitability increase slightly with depth. However, the means for the $150 \mathrm{~m}$ stations are obviously influenced by the low diversity/equitability of the $150 \mathrm{~m}$ station on the most 


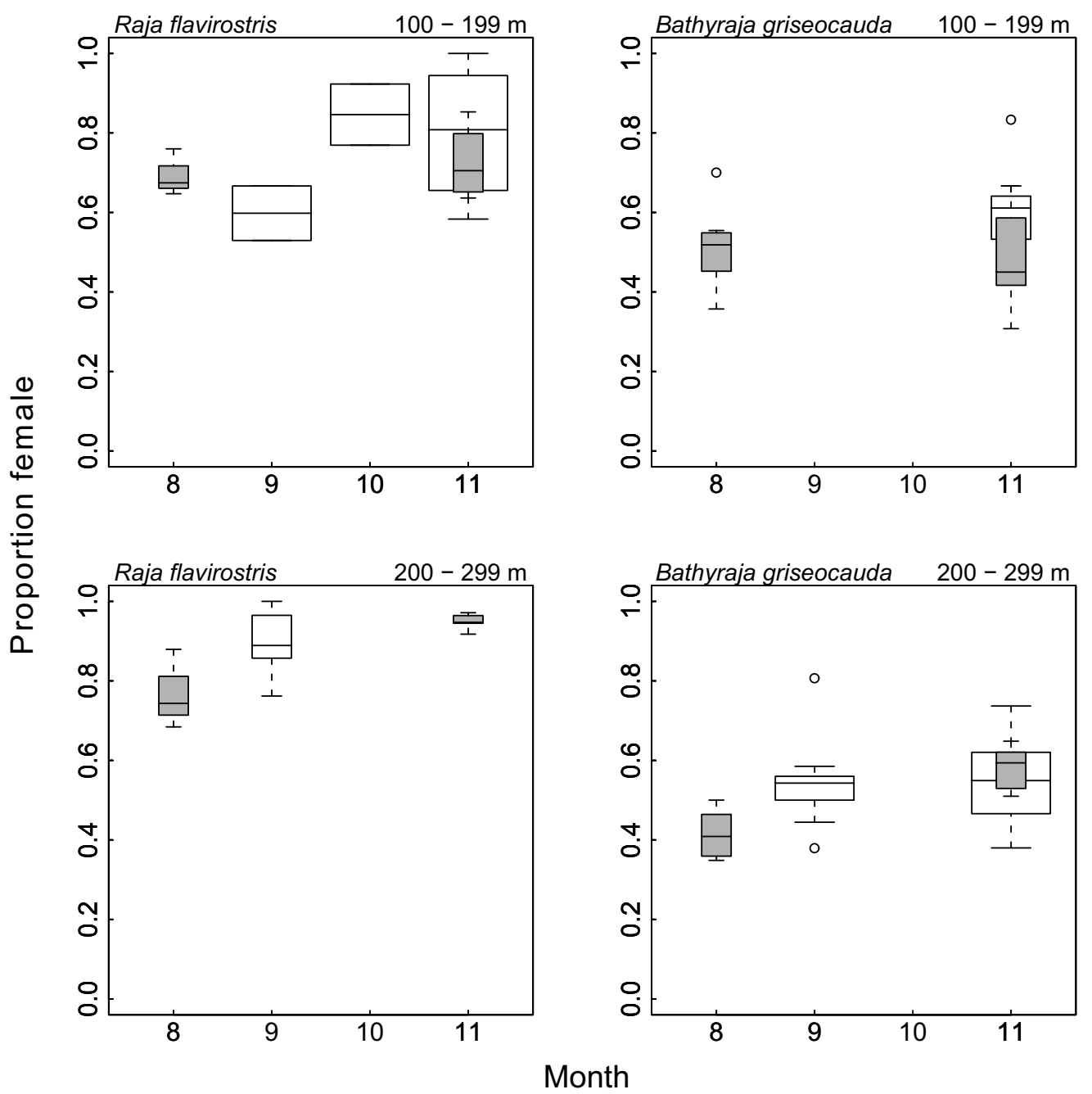

Fig. 9. The monthly distribution of the proportion of females in trawls where more than ten individuals were sexed in Raja flavirostris (left column) and Bathyraja griseocauda (right column). Trawls have been divided into two depth ranges (100-199 $\mathrm{m}$ and 200-299 m). The wider, unshaded boxplots are data from 2000, whereas the narrower, grey boxplots are data from 2001.

eastern transect (R5). With the exception of this station, diversity and equitability do not show great variation or consistent patterns. When the number of animals caught is used instead of catch weight, no overall trends in mean diversity and mean equitability are observed in the northern ray population.

For the commercial data, the Shannon diversity and equitability indices both show notable inter-annual variation. However, in none of the cases examined was there a significant trend in diversity or equitability index with year, where trend was defined as a significant positive or negative linear relationship. This held true even when depth and year were included as factors in a generalised linear model (GLM). A GLM of the form CPUE $=a+$ b.depth + c.year $+\mu$ was fitted in Splus statistical software, where $\mathrm{a}, \mathrm{b}$ and $\mathrm{c}$ are constants and $\mu$ is model error.

\section{Discussion}

This paper has reviewed trends in ray species abundance and the appropriateness of using a singlespecies stock assessment model. An updated stock assessment, based on the methods used by Agnew et al. (2000) suggests that the biomass of the northern ray assemblage has recovered. This follows a decline to around 37000 tonnes in the mid-1990s and reaching 46000 tonnes in 1999 . The biomass in 2001 was estimated 


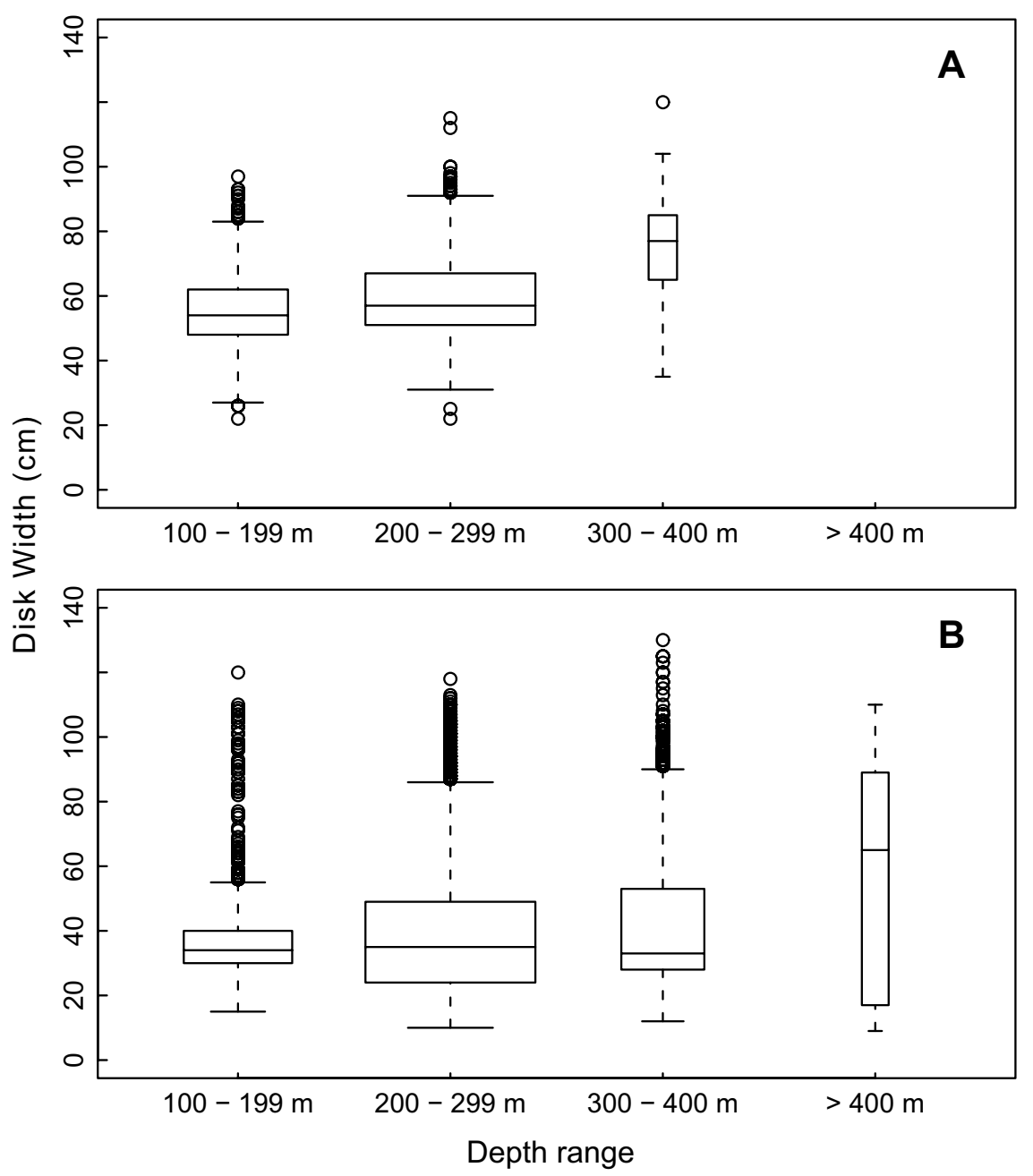

Fig. 10. Size (disk width) frequency distributions for (A) Raja flavirostris and (B) Bathyraja griseocauda in four depth ranges, using all data collected by Falkland Islands Fisheries Department observers and research cruises from 1988 to 2001 . Includes data from north and south of $52^{\circ} \mathrm{S}$.

at 43000 tonnes. This latest assessment suggests a higher biomass through the 1990s than previously reported by Agnew et al. (2000). The recovery of the stock during the latter half of the 1990s indicates that the precautionary management approach to limit catches in the early-1990s was appropriate, at least to the extent of rebuilding and maintaining the biomass of the overall assemblage. In its current form, the addition of Argentine total catch data did not improve the model fit. This suggests that the stocks currently fished are somewhat distinct, but much of the detailed spatial dynamics of the species fished remains to be established. In the meantime, the decline in stock biomass over the past two years (2000-01) confirms the need to maintain precautionary management and continue to limit directed fishing effort.
Treatment of the northern ray stock as a single unit, combined with known annual variation in the spatial distribution of fishing effort, suggests the need to check for local depletions in biomass. Local depletions may be masked in the overall CPUE series. Examination of gridby-grid CPUE series reveals high variability in catch rates, but no evidence for long-term local depletions in biomass. Local declines or extinctions of more vulnerable species could also be masked by the increase in abundance and biomass of smaller species that could result in the stability of the aggregated catch statistics (Dulvy et al., 2000). Examination of individual species CPUE trends reveals that three species (Bathyraja griseocauda, B. multispinis and the undescribed Bathyraja sp. 3) have shown a decline in relative abundance, whereas two Rajid spp. 


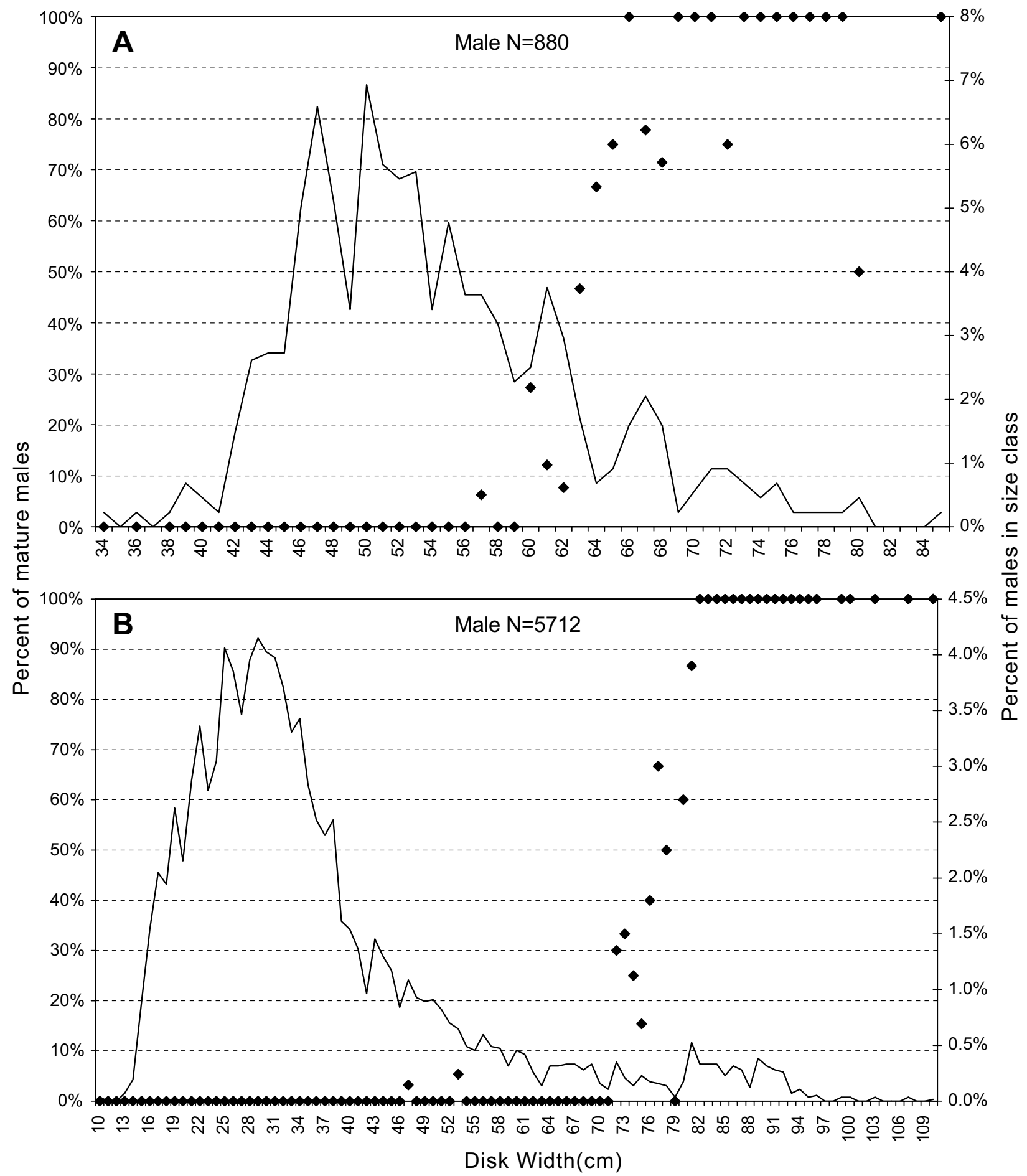

Fig. 11. The percent of mature (stage III) males by 1-cm disk width class in (A) Raja flavirostris and (B) Bathyraja griseocauda, based on observer data gathered in 2000 and 2001. Also shown is the size frequency distribution for males of each species. 
TABLE 5. Shannon diversity index $(H)$ and equitability $\left(E_{H}\right)$ for research trawls (R1-R5) at three depth zones with proportions calculated in terms of catch weight.

\begin{tabular}{lcccccccccccc}
\hline \hline & \multicolumn{2}{c}{ R1 } & \multicolumn{2}{c}{ R2 } & \multicolumn{2}{c}{ R3 } & \multicolumn{2}{c}{ R4 } & \multicolumn{2}{c}{ R5 } & \multicolumn{2}{c}{ Mean } \\
Depth & $H$ & $E_{H}$ & $H$ & $E_{H}$ & $H$ & $E_{H}$ & $H$ & $E_{H}$ & $H$ & $E_{H}$ & $H$ & $E_{H}$ \\
\hline 150 & 1.30 & 0.72 & 1.42 & 0.73 & 1.44 & 0.80 & - & - & 0.77 & 0.39 & 1.23 & 0.66 \\
200 & 1.47 & 0.76 & 1.40 & 0.78 & 1.63 & 0.74 & - & - & 1.37 & 0.66 & 1.47 & 0.73 \\
350 & 1.68 & 0.86 & 1.41 & 0.72 & - & - & - & - & 1.48 & 0.76 & 1.52 & 0.78 \\
Mean & 1.48 & 0.78 & 1.41 & 0.75 & 1.54 & 0.77 & - & - & 1.21 & 0.60 & - & - \\
\hline
\end{tabular}

TABLE 6. Shannon diversity index $(H)$ and equitability $\left(E_{H}\right)$ for research trawls (R1-R5) at three depth zones with proportions calculated in terms of catch numbers.

\begin{tabular}{lcccccccccccc}
\hline \hline & \multicolumn{2}{c}{$\mathrm{R} 1$} & \multicolumn{2}{c}{$\mathrm{R} 2$} & \multicolumn{2}{c}{$\mathrm{R} 3$} & \multicolumn{2}{c}{$\mathrm{R} 4$} & \multicolumn{2}{c}{$\mathrm{R} 5$} & \multicolumn{2}{c}{ Mean } \\
Depth & $H$ & $E_{H}$ & $H$ & $E_{H}$ & $H$ & $E_{H}$ & $H$ & $E_{H}$ & $H$ & $E_{H}$ & $H$ & $E_{H}$ \\
\hline 150 & 1.49 & 0.83 & 1.54 & 0.79 & 1.68 & 0.94 & - & - & 1.06 & 0.54 & 1.44 & 0.78 \\
200 & 1.73 & 0.89 & 1.54 & 0.86 & 1.87 & 0.85 & - & - & 1.77 & 0.85 & 1.72 & 0.86 \\
350 & 1.70 & 0.87 & 1.41 & 0.72 & - & - & - & - & 1.58 & 0.81 & 1.56 & 0.80 \\
Mean & 1.64 & 0.86 & 1.49 & 0.79 & 1.78 & 0.90 & - & - & 1.47 & 0.74 & - & - \\
\hline
\end{tabular}

( $R$. doellojuradoi and $R$. flavirostris) appear to have increased in relative abundance. The apparent increase of a large rajid species ( $R$. flavirostris) suggests that body size may not always provide a useful indicator of species vulnerability (Dulvy and Reynolds, 2002). However, this might indicate that the species dynamics within the northern ray assemblage is more complex than for the Northwest Atlantic (see Dulvy et al., 2000). In part, this complexity might be due to the movement of animals between political and statistical boundaries. The variation in distribution and spatial dynamics of the species within the rajid assemblage obviously implies that different species will experience differential fishing mortality. Likewise, variations in life history characteristics (growth rate, age/size-at-maturity and fecundity) will produce variation between species in their resistance to fishing pressure. Bathyraja griseocauda, which has shown a decline in abundance, is known to be a slow growing, long-lived species (Gallagher, 2000) and only 4.6\% of males found were above the size at $50 \%$ maturity. In contrast, $R$. flavirostris, a species that shows evidence of an increase in abundance over the past decade, had $12.8 \%$ of males above the size at $50 \%$ maturity. No studies of the growth rate of $R$. flavirostris have been carried out to date.

Fishery independent data showed a "snap shot" in which both bathymetric and geographical variation in the distribution of the species assemblage is apparent. Some insight into the movement of particular rajid species is possible using observer data. However varying spatial coverage, coupled with vessel effects, suggest considerable caution in the interpretation of these data. There is some evidence that Raja flavirostris is a highly mobile species, possibly moving westwards out of the Falklands zones towards the end of the year. The predominance of female $R$. flavirostris is consistent with a species undertaking feeding migrations to the Falklands zones. It is often observed that females generally travel further and so predominate at the edges of a species' feeding range; e.g. hakes (Tingley et al., 1995) and oceanic squids (Zuev et al., 1985). In contrast, there is no evidence for large spatial or temporal movements by B. griseocauda and this species may complete its entire lifecycle within Falkland Islands waters.

Changes in the composition of the northern ray assemblage are inevitable when species with different life histories are subject to unselective fishing. The loss of slow growing, long-lived species, and their replacement by faster growing species, has been a feature of several rajid fisheries across the world (see, for example, Pawson and Vince, 1999). One way to quantify the changes in diversity resulting from fishing pressure is the calculation of diversity indices, such as the Shannon index used here. No consistent declines or increases in the indices were detected over time (1994-2002) suggesting relative diversity is currently being conserved in this fishery. This is perhaps surprising given the observed decline in relative abundance of B. griseocauda, and increases in that of the two Raja species. Fishery independent data, however, confirm that the indices used may be relatively insensitive 
to the detailed species composition. In terms of diversity, as measured by the indices employed here, a decline in one species can be compensated for by an increase in another. Whilst the apparent overall maintenance of diversity is an encouraging result, it must be appreciated that this does not imply that there has been no change in the make up of the rajid species assemblage, and attention must still be given to the fate of individual species. The closing of the once heavily exploited area to the south of the Falklands to the directed ray fishery currently provides one refuge for species, such as B. griseocauda. These species are not resistant to fishing pressure even when maintained within conservative limits.

\section{Acknowledgements}

We are grateful to the Falkland Islands Fisheries Department observers who collected the majority of the biological data used here and the data entry staff who manage the catch and effort data from vessels. We thank the Falkland Islands Fisheries Department Director of Fisheries, John Barton, for supporting this work and Alexander Arkhipkin, Paul Brickle, Simeon Hill, Tom Marlow and two anonymous reviewers for their helpful comments on the manuscript.

\section{References}

AGNEW, D. J., C. P. NOLAN, and J. POMPERT. 1999. Management of the Falkland Island's skate and ray fishery. In: Case studies of the management of elasmobranch fisheries. R. Shotton (ed.). FAO Fish. Tech. Pap., 378: $268-284$.

AGNEW, D. J., C. P. NOLAN, J. R. BEDDINGTON, and R. BARANOWSKI. 2000. Approaches to the assessment and management of multispecies skate and ray fisheries using the Falkland Islands fishery as an example. Can. J. Fish. Aquat. Sci., 57: 429-440.

COUSSEAU, M. B., and R. G. PERROTTA. 2000. Peces Marinos de Argentina: Biología, distrbución, pesca.
INIDEP, Mar del Plata, $167 \mathrm{p}$.

DULVY, N. K., J. D. METCALF, J. GLANVILLE, M. G. PAWSON, and J. D. REYNOLDS. 2000. Fishery stability, local extinctios, and shifts in community structure in skates. Conserv. Biol., 14: 283-293.

DULVY, N. K., and J. D. REYNOLDS. 2002. Predicting extinction vulnerability in skates. Conserv. Biol., 16: 440-450.

FALKLANDS ISLANDS GOVERNMENT. 1997. Fisheries Department Fishery Statistics, Volume 1, 1997. Falkland Islands government printing office, Stanley, Falkland Islands, $75 \mathrm{p}$.

2002. Fisheries Department Fishery Statistics, Volume 6, 2001. Falkland Islands government printing office, Stanley, Falkland Islands.

GALLAGHER, M. J. 2000. The fisheries biology of commercial ray species from two geographically distinct regions. $\mathrm{PhD}$ thesis, University of Dublin.

GARCÍA DE LA ROSA, S. B., F. SANCHEZ, and L. B. BRUNO. 2000. Rayas. Pesca de altura. In Síntesis del estado de las pesquerías marítimas argentinus y de la Cuenca del Plata. Años 1997-1998, con una actualizatión de 1999. S. Bezzi, R. Akselman, and E. Boschi (eds.). Publicaciones especiales. INIDEP, Mar del Plata, $388 \mathrm{p}$.

HOLDEN, S., G. P. KIRKWOOD, and M. BRAVINGTON. 1995. C.E.D.A.: catch and effort data analysis, version 2.01. Marine Resources Assessment Group Ltd., 18 Queen Street, London, WJ1 5PN, UK.

PAWSON, M., and M. VINCE, 1999. Management of shark fisheries in the Northeast Atlantic. In: Case studies of the management of elasmobranch fisheries. R. Shotton (ed.). FAO Fish. Tech. Pap., 378: 1-46.

TINGLEY, G. A., L. V. PURCHASE, M. V. BRAVINGTON, and S. J. HOLDEN. 1995. Biology and fisheries of hakes (M. hubbsi and M. australis) around the Falkland Islands. In: Hake: biology, fisheries and markets. J. Alheit and T. J. Pitcher (eds.). Chapman \& Hall, London, p. 269-303.

ZAR, J. H. 1999. Biostatistical analysis. [ $4^{\text {th }}$ edition]. Pretence Hall, 663 p.

ZUEV, G. V., C. H. M. NIGMATULLIN, and G. V. NIKOLSKY. 1985. Nektonic oceanic squids. Moscow, Agropromizdat, (In Russian) 223 p. 